\title{
The Effect of Deep Eutectic Solvents as Co-solvent on Organophosphorus Hydrolase Targeting Engineering
} Enzyme-catalyzed

\author{
Morteza Mirzaei ${ }^{1,2} \mathbb{( D}$, Hasan Khorshahi ${ }^{2}$, Hamid Tebyanian ${ }^{3}{ }^{\mathbb{D}}$, Rezvan Seid Moradi ${ }^{2}$, Mona Rastegar ${ }^{2}$, \\ Shariat Panahi ${ }^{2}$, Reyhaneh Sariri ${ }^{1}$, Ali Mohammad Latifi 2,* (D) \\ Department of Biology, Faculty of Sciences, University of Guilan, University Campus 2, Rasht, Iran \\ Applied Biotechnology Research Center, Baqiyatallah University of Medical Sciences, Tehran, Iran \\ Research Center for Prevention of Oral and Dental Diseases, Baqiyatallah University of Medical Sciences, Tehran, Iran \\ * Correspondence: amlatifi290@gmail.com;
}

Scopus Author ID 54880840300

Received: 25.04.2020; Revised: 10.05.2020; Accepted: 11.05.2020; Published: 13.05.2020

\begin{abstract}
Deep eutectic solvents (DESs) are systems formed from one or more compounds in a mixture form, to give a eutectic with a melting point much lower than either of the individual components. DESs have attracted considerable attention as green alternative solvents to conventional solvents because they are not only eco-friendly, non-toxic, and biodegradable organic compounds, but also low cost and easy to produce.and share several features and properties. DESs not only have particular properties in comparison with traditional organic solvents, but also their combination with organic solvents may also show improved and desired properties. In this study, DESs were used as the solvent in buffer containing organophosphorus hydrolase enzyme, in order to optimize the enzyme reaction buffer. Different DESs such as reline (choline chloride 2:1 urea), ethaline (choline chloride 2:1 ethanol) and glyceline (choline chloride 2:1 glycerol) were selected as an adjuvant for OPH enzyme reaction buffer. Biochemical properties, thermal stability and half-life of the OPH enzyme were studied, accordingly. In the reline, a reduction in the activity of the enzyme and in ethaline and glyceline, an increase in the activity and the stability were observed when compared with the buffer. The highest activity and stability in ethaline and glyceline in molar fraction was 0.025 and 0.25 , respectively.
\end{abstract}

Keywords: Deep eutectic solvents; Choline chloride; Organophosphorus hydrolase; Reline; Ethaline; Glyceline.

(C) 2020 by the authors. This article is an open access article distributed under the terms and conditions of the Creative Commons Attribution (CC BY) license (https://creativecommons.org/licenses/by/4.0/).

\section{Introduction}

Since enzymes as catalysts are involved in biochemical reactions which speed up the rate of the reactions, therefore the selection of a suitable solvent is considered as a critical issue [1]. Recently, non-aqueous solvents have been used to promote enzymatic processes rather than aqueous solvents [2,3]. Over the past two decades, engineering of enzymatic solvents and enzymes has been studied extensively. Determining factors that cause fundamental and influential enzymatic changes are the key elements in enzyme processes which include solvents and effective conditions for enzyme activity such as $\mathrm{pH}$, aqueous activity, surfactants and ionic liquids etc., that are used to increase the efficiency of enzymatic processes [4, 5]. Therefore, these factors alter the nature of the reaction buffer dramatically. In the present research, we discuss the effect of deep eutectic solvents (DESs) as a novel class of solvents [6, 7]. The published reports indicate the potential of ionic liquids as solvents for enzymatic reactions. In 
particular, in bioconversion processes compared with conventional organic solvents, enzymes in ionic liquids own higher activity, better stability and more selectivity which indicates the positive effect of these solvents on enzymatic reactions [8]. Bioactive reactions can occur in ionic liquids $[9,10]$, hence, the catalytic activity, stability and the structure of enzymes in DESs have been broadly investigated [11]. DESs are a group of ionic liquid [12] solvents composed of a mixture of cheap polar molecules (liquids or solids) which the melting temperature drops sharply when combined $[6,9,13]$.

Solvent and solvent interactions in the solvent mixture are much more complex than pure solvents due to the possibility of preferential solvation and solvent-solvent interactions [14]. Therefore, DESs can be used as solvents in a mixture of binary or triple solvents to increase the efficiency of processes and to promote the physical and chemical properties of solvents [15].

Organophosphorus compounds (OPs) are among the class of highly toxic substances, which are used as pesticides and insecticides, as well as nerve agents. The widespread use of these compounds increases public concern due to its adverse effects on human health and the environment by contaminating the soil, sediments and groundwater [13, 16, 17]. Given the recent advances in the biological sciences, the use of microorganisms to destroy these toxic substances as an economical and constructive tool compared to other common approaches seems appropriate [18, 19]. The Organophosphorus hydrolase enzyme is capable of hydrolyzing various OPs $[4,13,16]$. However, the thermal stability is low and the enzyme's profile significantly limits its industrial applications [20].

Regarding the importance of OPH as an important and effective enzyme in the biological system, as well as the tendency to examine the enzymatic behavior in non-aqueous media and especially solvents with suitable environmental characteristics, the OPH enzyme's behavior were investigated in three different media. The media contained three most commonly used solvents with DES, including reline (choline chlorid 1:2 urea), ethaline (cholinechloride 1:2 ethylen glycole) and glyceline (choline chlorid 1:2 urea) that This particular type of solvents will provide guidance to design and develop truly green solvents with both lowtoxicity and high biodegradability $[12,14-16]$. This research investigated these interactions in new solvent media (such as DESs) along with their mixtures containing the buffers. In each part of this research, studies on activity, stability and half-life performed concurrently so that the results are used in order to provide a comprehensive interpretation of the changes in the way the OPH enzyme works.

\section{Materials and Methods}

In the present study, the effect of DESs was evaluated on the OPH function in the presence of several mole fractions of reline, ethaline and glycelin. For this purpose, in the beginning, the activity of the $\mathrm{OPH}$ in different mole fractions was tested, followed by thermal stability and the half-life assays in order to optimize the function of the enzyme in the reaction buffer.

\subsection{Material.}

Ethylene glycol ( $\geq 99.8 \%$ ), glycerol ( $\geq 99.5 \%$, spectrophotometric grade) and urea (99\%) were purchased from Merck. All solvents were dried by $3 \AA$ molecular sieve. The water content of the dried materials was determined by coulometric Karl Fisher titration yielding 
$<500 \mathrm{ppm}$ residual water, choline chloride and paraoxon were obtained from Sigma-Aldrich, choline chloride was dried at $50^{\circ} \mathrm{C}$ in a vacuum oven for $24 \mathrm{~h}$.

\subsection{Synthesis of DESs.}

In order to prepare Reline, Ethaline, and Glyceline, choline chloride were mixed with urea, ethylene glycol, and glycerol as hydrogen bond donor (HBD), respectively. The material mixed and stirred while heating (near $80^{\circ} \mathrm{C}$ ) until a homogeneous, colorless liquid formed.

\subsection{Protein expression and purification.}

The recombinant Rosetta-gami containing the OPH enzyme-encoding gene obtained from previous research [21]. The bacterial strain cultured in a $5 \mathrm{ml}$ culture medium containing $50 \mu \mathrm{g} / \mathrm{ml}$ kanamycin for $16 \mathrm{~h}$. In the next step, $100 \mu \mathrm{l}$ of pre-culture was inoculated in $100 \mathrm{ml}$ of fresh culture medium containing kanamycin and incubated to $\mathrm{OD}_{600} 0.8$ at $37^{\circ} \mathrm{C}$. IPTG as the inducer added with a final concentration of $1 \mathrm{mM}$ and after $5 \mathrm{~h}$, the cells collected by centrifugation at $9000 \mathrm{rpm}$ for $5 \mathrm{~min}$ and washed with $50 \mathrm{mM}$ Tris-HCl buffer $(\mathrm{pH} 8)$. After the addition of lysis buffer (50 mM Tris-HCl, 3\% TritonX-100, 8 mM EDTA, $8 \%$ sucrose), sonication was performed on ice. In order to isolate the intact cells, a 4-min centrifugation performed at $2500 \mathrm{rpm}$ and then the supernatant centrifuged for isolation of the inclusion bodies with a $12000 \mathrm{rpm}$ for $15 \mathrm{~min}$. The washing of inclusion bodies carried out with $50 \mathrm{mM}$ Tris buffer ( $\mathrm{pH} \mathrm{8),} 3 \mathrm{M}$ urea, and 8\% sucrose [22]. The obtained precipitate used for protein refolding by dissolving in $8 \mathrm{M}$ urea and gradually decreasing the concentration of urea [23]. Finally, the concentration of refolded protein calculated by Bradford method.

\subsection{Spectrophotometric measurements.}

The buffer mixture was prepared with DESs in different mole fractions $( \pm 0.01 \mathrm{mg})$. To investigate the paraoxon degradation reaction, the spectrophotometric measurements was performed by Biochrom WPA Biowave II+ in the wavelength range of $405 \mathrm{~nm}$, which is the absorption spectrum of 4-nitrophenol (as the reaction product). Other components such as solvents, reactant agents and intermediate products showed no absorbance in this wavelength range.

\subsection{OPH activity assay.}

To investigate the effects of DESs on enzyme activity, paraoxon was analyzed for production of 4-nitrophenol in the presence of different mole fractions of DESs containing 0, $0.025,0.05,0.075,0.1,0.25$ of ethaline, glyceline and reline buffer mixtures. In order to evaluate the enzyme activity, OPH (final concentration of $3.0 \times 10^{-2} \mathrm{mg} / \mathrm{ml}$ ) and paraoxon (final concentration of $2 \mathrm{mM}$ ), were added to reaction buffer $(\mathrm{pH} 8)$ in final concentration of 1 $\mathrm{ml}$ and incubated at $37^{\circ} \mathrm{C}$. Finally, the activity was measured at $405 \mathrm{~nm}$, followed by the detection of $\mathrm{p}$-nitrophenol, produced by enzymatic hydrolysis of parathion, which creates yellow color. The enzyme activity was assayed following increasing the mole fraction of DES in the mixture. The control sample included the enzyme in the presence of buffer reaction and the rest of the activities calculated according to the control sample. Before reading the ODs, the extinction coefficients of paraoxon degradation to 4-nitrophenol calculated in the total molar fraction of reline, ethaline and glyceline. These experiments were conducted at the ideally $\mathrm{pH}$-controlled environment and were repeated three times. It is worth noting that, the 
activity of the OPH in the buffer in the absence of DESs, was considered as the control in order to calculate the activity. Furthermore, paraoxon hydrolysis evaluated in the presence of all mole fractions and its amount deduced from the results of mole fractions to investigate the effect of DES on spontaneously hydrolysis of parathion.

\subsection{Thermostability.}

As demonstrated in the previous studies, thermal destruction of OPH enzyme occurs at $65^{\circ} \mathrm{C}$ after several minutes [24, 25]. The thermal stability assay was performed in the presence of various mole fractions of ethaline and glyceline DESs, at $65^{\circ} \mathrm{C}$. The incubation mixture contained $\mathrm{OPH}$ with concentration of $3.0 \times 10^{-2} \mathrm{mg} / \mathrm{ml}$ along with paraoxon (final concentration of $2 \mathrm{mM})$, in a volume of $1 \mathrm{ml}$ of the reaction mixture $(\mathrm{pH} 8)$. The mixture was incubated for $15 \mathrm{~min}$ in the presence of different mole fractions of the DESs at $65^{\circ} \mathrm{C}$. The samples were cooled on ice followed by the addition of paraoxon in order to assay the enzymatic hydrolysis at $37^{\circ} \mathrm{C}$. In order to calculate and compare the activity accurately, before and after the thermal shock, the enzyme activity at $37^{\circ} \mathrm{C}$, in the presence of buffer and absence of DES was set as the control. On the other hand, the stability of the OPH enzyme at room temperature $\left(25^{\circ} \mathrm{C}\right)$ was evaluated by incubation of the enzyme in mixtures of ethaline and glyceline with buffer. Samples were assayed for their activity at different time intervals $(0,24$, $50,96,125$ and $168 \mathrm{~h}$ ), by addition of $2 \mathrm{mM}$ of paraoxon in the reaction buffer. The activity was calculated to monitor the changes in activity relative to the starting time of the enzymecatalyzed reaction $\left(\mathrm{t}_{0}\right)$. In addition, the half-life $\left(\mathrm{t}_{1 / 2}\right)$ of the $\mathrm{OPH}$ enzyme was measured at $25^{\circ} \mathrm{C}$. The tests presented here were performed in triplicate in order to obtain valid results.

\section{Results and Discussion}

Deep eutectic solvents (DESs) have already gained widespread attention to expand their applications in different areas due to their environmental and economic prospects. Hence, many enzymatic reactions have been conducted in DESs aiming to increase the activity and stability of enzymes in catalytic biological reactions [11]. Since DESs are able to affect the profile of enzyme activity and stability [26], it was decided to study these changes by designing a set of experiments involving OPH enzyme. The purpose was to represent an optimal formulation, which significantly modifies the enzyme functionality.

\subsection{Enzyme activity assay.}

In this study, the ability of DESs in elevating the enzyme activity was studied by measuring the progress of the OPH-catalyzed reaction in aqueous buffer solution and different concentrations of DES. The obtained results of the enzyme activity in three mixture buffers of reline, ethaline and glyceline in different mole fractions are demonstrated in figure 1. Reduced activity was observed during the reline mole fraction enhancement. Reline buffer contains urea, affecting the protein structure which results in a continuous decrease in mole fraction of 0.1 to the extent that the enzyme almost lost its activity [27]. OPH activity elevated relative to the increase of the ethaline mole fraction in the mixture, compared to the enzyme activity in the buffer. The increase in the mole fraction of $\mathrm{XEt}=0.075$ was more noticeable than the control sample. The maximum activity was reported in the mole fraction of 0.025 ; however, the enzyme almost lost its activity in the mole fraction of 0.25 . Upon the increase of glyceline in the buffer to the mole fraction of 0.1 , OPH activity increased accordingly. The maximum 
activity was observed in the mole fraction of 0.025 , followed by increasing the glyceline to the mole fraction of 0.25 , which caused a decrease in activity to an extent that it reached slightly near the amount of the control sample. Due to the sharp decline in the activity in mole fraction of 0.25 and more, following up the amount of activity was impossible therefore, higher mole fractions were excluded from the experiments.

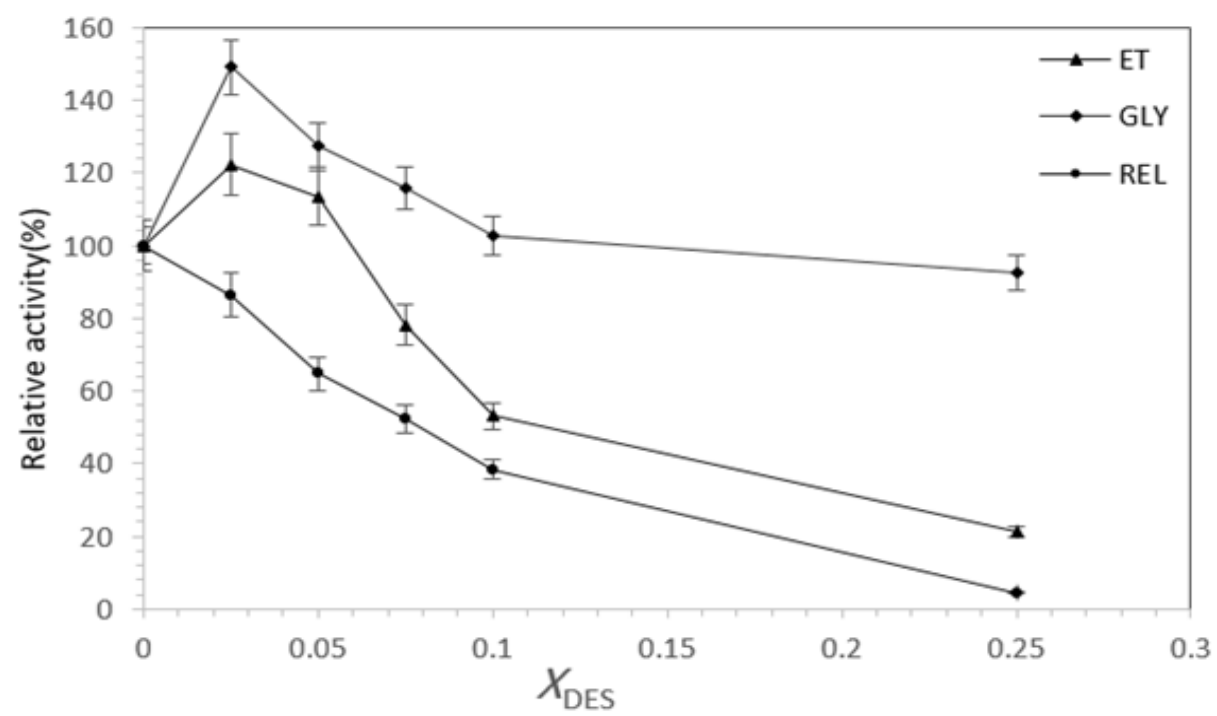

Figure 1. Effects on organophosphorus hydrolase activity in the presence of increasing mole fraction of reline [28], ethaline [29] and glyceline (GLY) as deep eutectic solvents ( Retained enzyme activity was measured, $1 \mathrm{mg} / \mathrm{ml}$ enzyme concentration and 0.1 Tris- $\mathrm{HCl}$ buffer, $\mathrm{pH} 8.0,2 \mathrm{mM}$ paraoxon, in the presence of deep eutectic solvents $(\leq \mathrm{x}=0.25)$.

Upon analyzing results obtained from previous experiments, ethaline and glyceline were chosen for further analysis. Reline was dismissed due to its denaturing effect on enzyme. The observed changes in the buffer mixtures containing ethaline and glyceline can be due to the fact that: (a) One of the known properties of DESs is the formation of a hydrogen bond between the HBD species and the halogen ion present in chlorine chloride salt. The used DESs in this study contain chloride depletion anions. However, the molar concentration of these chlorides decreases during the preparation of DES by addition of 1:2 choline chloride to glycerol and ethylene glycol (HBD), which here the glycerol and ethylene glycol have a tendency to form hydrogen bonds with chloride, therefore the likelihood to leave a negative effect on OPH enzymes is greatly reduced [30]. b) The hydrophilic nature of DESs allows the water molecules to act differently, which confers a new function to the water molecules and this effect is observed by increased activity in the mole fraction of 0.025 of ethaline and glyceline. c) In the mole fraction of more than 0.025, the DES concentrations of ethaline and glyceline were increased tremendously which led to the declination in the enzyme activity. Viscosity is regarded as a vital factor in enzyme activity. Solvent viscosity affects rate of biocatalytic chemical reactions due to mass transfer limitations [31].

Given the increase in the amount of ethaline and glyceline in the water, the viscosity of the mixture elevates and the motility of enzyme and other components decreases exceedingly. In previous studies, it has been observed that the enzyme activity decreases relative to viscosity $[28,32]$, which here in this study, by increasing the viscosity and increasing the mole fraction of the ethaline and glyceline in the buffer, the ability of the enzyme to conduct the hydrolysis reaction decreases and therefore the enzyme activity reduces dramatically. 


\subsection{Thermostability of $\mathrm{OPH}$.}

Improvement in the thermal stability of the enzyme is one of the outstanding effects of DESs [33]. In this study, the mole fraction of ethaline and glyceline is the indicator used to assess the OPH activity changes. Obtained amounts of activities were calculated after deducing the control amounts in order to study and observe the thermostability of OPH against high temperature. A reduction of activity occurred following the increasing mole fraction of ethaline and glyceline. The enzyme exhibited higher activity in mole fraction of glyceline, compared to ethaline, which indicates the thermal stability of $\mathrm{OPH}$, and it can be concluded that the thermostability of OPH enzyme increases in the presence of the mole fraction of rich solvents of ethaline and glyceline (Figure 2).

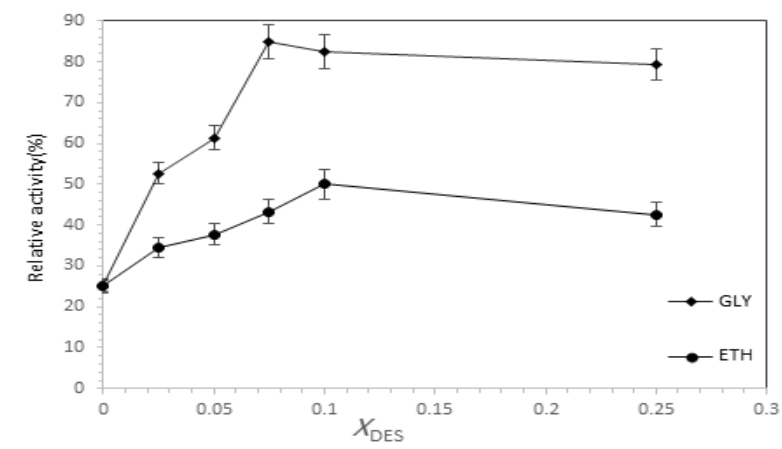

Figure 2. Effects on OPH activity in the presence of increasing mole fraction of ethaline and glyceline after 15 $\min$ in $\mathrm{T}=60^{\circ} \mathrm{C}$ to calculate thermal stability. Retained enzyme activity was measured in $1 \mathrm{mg} / \mathrm{ml}$ enzyme concentration and 0.1 Tris-HCl buffer, $\mathrm{pH} 8.0,2 \mathrm{mM}$ paraoxon, in the presence of deep eutectic solvents $(\leq \mathrm{x}=$ $0.25)$.

Despite the activity decline in all mole fractions, this decrease in activity can be tracked down in high mole fractions of ethaline and glyceline. The results displayed in figures 1 and 2 show that in the mole fraction of 0.25 of ethaline, only $12 \%$ of the activity was reduced while the activity in the lower mole fraction, such as 0.025 with the maximum activity, decreased by $61 \%$ and it decreased even more in the control sample by $75 \%$. Similarly, buffer containing glyceline, the activity reduction was observed in the mole fraction of 0.25 and 0.025 , which decreased by $14 \%$ and $68 \%$, respectively. It can be concluded that the enzyme's stability in high mole fractions of DESs at high temperatures is remarkably high. As mentioned earlier, increasing the DES concentration enhances the thermal stability of $\mathrm{OPH}$, which this characteristic is due to proper solvation of the enzyme by DESs, thus protecting the enzyme against the temperature.

\subsection{Half-life $\mathrm{OPH}$.}

In this section, the sustainability of OPH in mole fraction of ethaline and glyceline along with buffer was evaluated. These compounds are known to have an effect on the stability and half-life of the enzyme [26]. The OPH enzyme in the control sample lost its activity completely after a total of $168 \mathrm{~h}$. The higher the concentration of ethaline and glyceline, the lower the amount of change occurs in the activity, so that it lost only $30 \%$ of its activity in the mixture of $0.25 \%$ of ethaline after $168 \mathrm{~h}$. In the mixture of glyceline with buffer in the mole fraction of 0.25 after $168 \mathrm{~h}$, the enzyme lost just $15 \%$ of its activity. These results indicate the high stability of $\mathrm{OPH}$ in the rich mole fractions of ethaline and glyceline, therefore lower amounts of change occur in the activity, so that OPH lost only $30 \%$ of its activity (Figures 3 and 4). The half-life 
of the OPH is reported in table 1 and it increases in DES solutions. In addition, OPH adopts longer half-life in DES solutions containing glyceline compared to ethaline. As a result, according to the results of the previous studies on the OPH half-life improvement [34], by applying DES solution, a new formulation of enzyme reaction can be obtained in order to enhance the stability of the enzyme.

Table 1. Half-life (hour) of enzyme activity during prolonged incubation of OPH in various mole fraction of ethaline and glyceline with buffer, $\mathrm{pH} 8, \mathrm{~T}=37^{\circ} \mathrm{C}$.

\begin{tabular}{c|c|c}
\hline $\begin{array}{c}\text { Storage condition } \\
\left(\boldsymbol{x}_{\text {DES }} \text { in buffer }\right)\end{array}$ & Ethaline & Glyceline \\
\hline 0 & 60 & 60 \\
\hline 0.025 & 68 & 126 \\
\hline 0.05 & 80 & 128 \\
\hline 0.075 & 96 & 137 \\
\hline 0.1 & 165 & 169 \\
\hline 0.25 & $>170$ & $>170$ \\
\hline
\end{tabular}

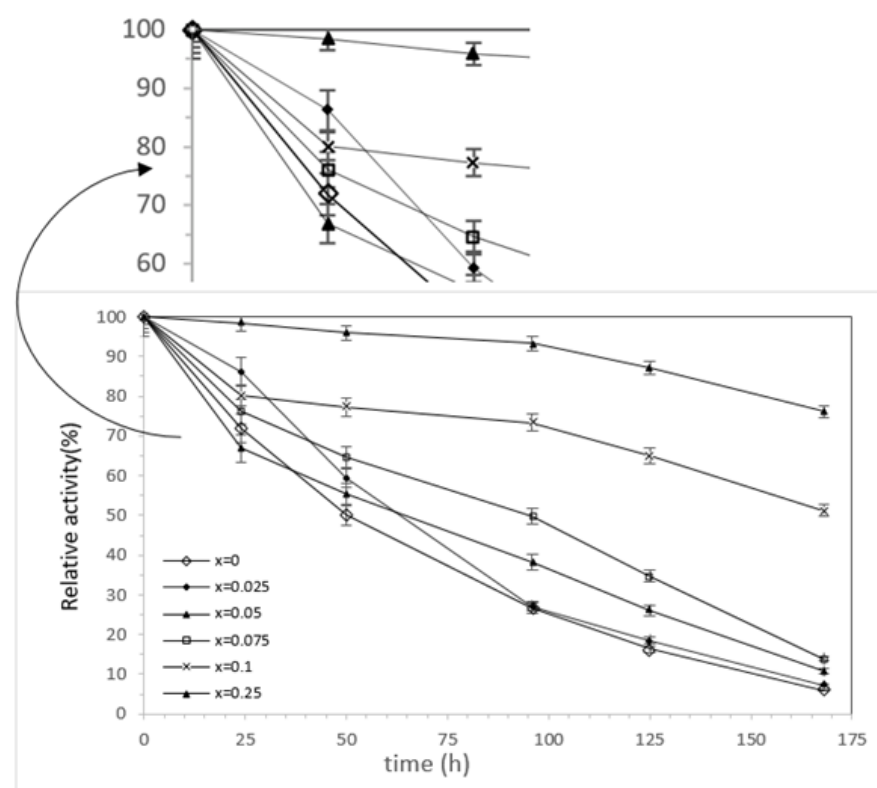

Figure 3. Relative activities of $\mathrm{OPH}$ in the presence of aqueous solutions containing glyceline mixtures and dried paraoxon, Constant amounts of enzyme concentration $(1 \mathrm{mg} / \mathrm{ml})$ and paraoxon $(2 \mathrm{mM})$ were used, $\mathrm{T}=25^{\circ} \mathrm{C}$.

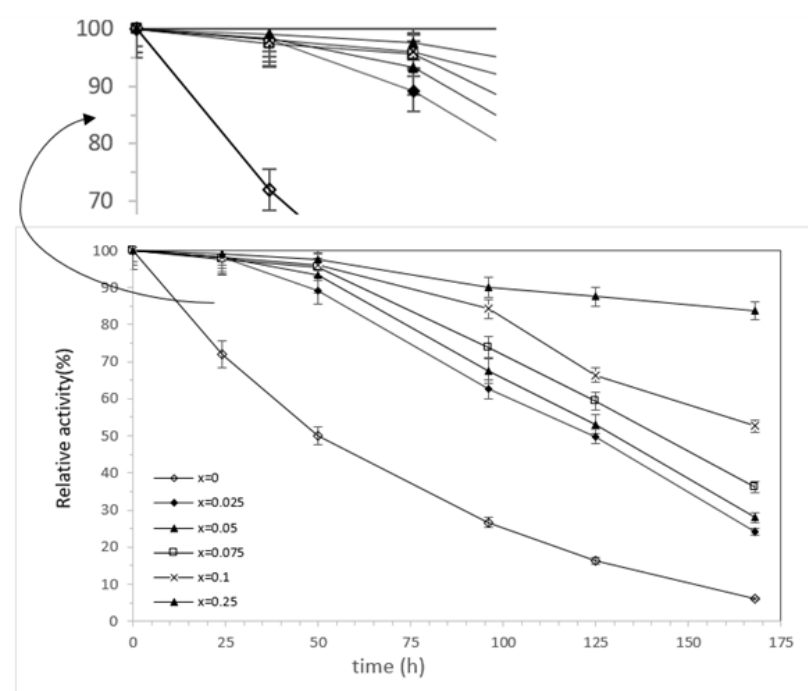

Figure 4. Relative activities of $\mathrm{OPH}$ in the presence of aqueous solutions containing ethaline mixtures and paraoxon, Constant amounts of enzyme concentration $(1 \mathrm{mg} / \mathrm{ml})$ and paraoxon $(2 \mathrm{mM})$ were used, $\mathrm{T}=25^{\circ} \mathrm{C}$. 


\section{Conclusions}

This study was conducted to evaluate the effect of DES on thermal stability and halflife of OPH enzyme in order to improve the enzyme function. In the lower mole fractions of ethaline and glyceline DESs with buffer, the activity of OPH increases, but as we move forward to higher DES concentrations, it is inversely proportional to activity and directly proportional to enzyme stability, but instead the stability of the OPH increases. This amount of increase in the activity and stability of the OPH in mixtures of glyceline is higher than the ethaline. It also demonstrates that DESs can leave a positive effect on the activity, but in the higher mole fractions of DESs due to an increase in factors such as viscosity, the activity drops. Nevertheless, the stability of the OPH enzyme in mole fractions of 0.25 and 0.1 , in which the concentration of ethaline and glyceline is high, the half-life of the OPH enhances eminently. Since DESs are relatively easy to make, inexpensive, non-toxic and biodegradable, it seems that proper formulated DES solutions can be considered as an ideal solution in order to control the activity and stability of the OPH enzyme. With further investigations, this system can be used to develop enzyme protection and disinfectant systems for military and civilian applications.

\section{Funding}

This research received no external funding.

\section{Acknowledgments}

This work was supported by a grant from the Research Council of Baqiyatallah University of Medical Sciences.

\section{Conflicts of Interest}

The authors declare no conflict of interest.

\section{References}

1. Anastas, P.T.; Kirchhoff, M.M. Origins, current status, and future challenges of green chemistry. Acc Chem Res 2002, 35, 686-94, https://doi.org/10.1021/ar010065m.

2. Bi, Y.H.; Duan, Z.Q.; Li, X.Q.; Wang, Z.Y.; Zhao, X.R. Introducing biobased ionic liquids as the nonaqueous media for enzymatic synthesis of phosphatidylserine. J Agric Food Chem 2015, 63, 1558-61, https://doi.org/10.1021/jf505296k.

3. Kaar, J.L. Lipase Activation and Stabilization in Room-Temperature Ionic Liquids. Methods Mol Biol 2017, 1504, 25-35, https://doi.org/10.1007/978-1-4939-6499-4_4.

4. Guajardo, N.; Müller, C.R.; Schrebler, R.; Carlesi, C.; Dōmínguez de María, P. Deep Eutectic Solvents for Organocatalysis, Biotransformations, and Multistep Organocatalyst/Enzyme Combinations. ChemCatChem 2016, 8, 1020-1027, https://doi.org/10.1002/cctc.201501133.

5. Sheldon, R.A.; Pereira, P.C. Biocatalysis engineering: the big picture. Chem Soc Rev 2017, 46, 2678-2691, https://doi.org/10.1039/c6cs00854b.

6. Song, X.; Zhang, R.; Xie, T.; Wang, S.; Cao, J. Deep Eutectic Solvent Micro-Functionalized Graphene Assisted Dispersive Micro Solid-Phase Extraction of Pyrethroid Insecticides in Natural Products. Front Chem 2019, 7, 594, https://doi.org/10.3389/fchem.2019.00594.

7. Wang, T.F.; Lo, H.F.; Chi, M.C.; Lai, K.L.; Lin, M.G.; Lin, L.L. Affinity Immobilization of a Bacterial Prolidase onto Metal-Ion-Chelated Magnetic Nanoparticles for the Hydrolysis of Organophosphorus Compounds. Int J Mol Sci 2019, 20, 3625, https://doi.org/10.3390/ijms20153625.

8. Zhao, H. Protein Stabilization and Enzyme Activation in Ionic Liquids: Specific Ion Effects. J Chem Technol Biotechnol 2016, 91, 25-50, https://doi.org/10.1002/jctb.4837. 
9. Huang, P.; Li, B.; Feng, S.; Guo, Y.; Zhao, G.; Wang, D.; Liu, Q. Xuebijing injection for acute organophosphorus pesticide poisoning: a systematic review and meta-analysis. Ann Transl Med 2019, 7, 112, https://doi.org/10.21037/atm.2018.12.22.

10. Li, R.; Yang, J.; Xiao, Y.; Long, L. In vivo immobilization of an organophosphorus hydrolyzing enzyme on bacterial polyhydroxyalkanoate nano-granules. Microb Cell Fact 2019, 18, 166, https://doi.org/10.1186/s12934-019-1201-2.

11. Xu, P.; Zheng, G.W.; Zong, M.-H.; Li, N.; Lou, W.Y. Recent progress on deep eutectic solvents in biocatalysis. Bioresources and Bioprocessing 2017, 4, 34, https://doi.org/10.1186/s40643-017-0165-5.

12. Cardozo, M.; de Almeida, J.S.F.D.; Cavalcante, S.F.d.A.; Salgado, J.R.S.; Gonçalves, A.S.; França, T.C.C.; Kuca, K.; Bizzo, H.R. Biodegradation of Organophosphorus Compounds Predicted by Enzymatic Process Using Molecular Modelling and Observed in Soil Samples Through Analytical Techniques and Microbiological Analysis: A Comparison. Molecules 2020, 25, 58, https://doi.org/10.3390/molecules25010058.

13. Liu, H.; Jiang, L.; Lu, M.; Liu, G.; Li, T.; Xu, X.; Li, L.; Lin, H.; Lv, J.; Huang, X. Magnetic Solid-Phase Extraction of Pyrethroid Pesticides from Environmental Water Samples Using Deep Eutectic Solvent-type Surfactant Modified Magnetic Zeolitic Imidazolate Framework-8. Molecules 2019, 24, 4038, https://doi.org/10.3390/molecules24224038.

14. Harifi-Mood, A.R.; Khorshahi, H. Binary mixtures of dimethyl sulfoxide with methanol, ethylene glycol, and glycerol as solvent: Solvatochromism and chemical kinetics study. Journal of Molecular Liquids 2018, 259, 361-368, https://doi.org/10.1016/j.molliq.2018.03.039.

15. Harifi-Mood, A.R.; Sadrzadeh, S. Dimethyl sulfoxide/deep eutectic solvents mixtures as media in the reaction of 1-fluoro-2,4-dinitrobenzene with piperidine: A solvent effect study. Journal of Physical Organic Chemistry 2018, 31, e3787, https://doi.org/10.1002/poc.3787.

16. Liu, W.; Quan, J.; Hu, Z. Detection of Organophosphorus Pesticides in Wheat by Ionic Liquid-Based Dispersive Liquid-Liquid Microextraction Combined with HPLC. J Anal Methods Chem 2018, 2018, 8916393, https://doi.org/10.1155/2018/8916393.

17. Luo, R.; Feng, Z.; Shen, G.; Xiu, Y.; Zhou, Y.; Niu, X.; Wang, H. Acetylcholinesterase Biosensor Based On Mesoporous Hollow Carbon Spheres/Core-Shell Magnetic Nanoparticles-Modified Electrode for the Detection of Organophosphorus Pesticides. Sensors (Basel) 2018, 18, 4429, https://doi.org/10.3390/s18124429.

18. Burnworth, M.; Rowan, S.J.; Weder, C. Fluorescent sensors for the detection of chemical warfare agents. Chemistry 2007, 13, 7828-36, https://doi.org/10.1002/chem.200700720.

19. Knapton, D.; Burnworth, M.; Rowan, S.J.; Weder, C. Fluorescent organometallic sensors for the detection of chemical-warfare-agent mimics. Angew Chem Int Ed Engl 2006, 45, 5825-9, https://doi.org/10.1002/anie.200601634.

20. Su, F.-H.; Tabañag, I.D.F.; Wu, C.Y.; Tsai, S.L. Decorating outer membrane vesicles with organophosphorus hydrolase and cellulose binding domain for organophosphate pesticide degradation. Chemical Engineering Journal 2017, 308, 1-7, https://doi.org/10.1016/j.cej.2016.09.045.

21. Latifi, A.M.; Khajeh, K.; Farnoosh, G.; Hassanpour, K.; Khodi, S. The Cytoplasmic and Periplasmic Expression Levels and Folding of Organophosphorus Hydrolase Enzyme in Escherichia coli. Jundishapur J Microbiol 2015, 8, e17790, https://doi.org/10.5812/jjm.17790.

22. Palmer, I.; Wingfield, P.T. Preparation and extraction of insoluble (inclusion-body) proteins from Escherichia coli. Curr Protoc Protein Sci 2004, Chapter 6, https://doi.org/10.1002/0471140864.ps0603s38.

23. Burgess, R.R., Chapter 17 Refolding Solubilized Inclusion Body Proteins. In: Methods in Enzymology. Burgess, R.R. Editor. Academic Press, 2009; pp. 259-282, https://doi.org/10.1016/S0076-6879(09)63017-2.

24. Chu, X.Y.; Tian, J.; Wu, N.F.; Fan, Y.L. An intramolecular disulfide bond is required for the thermostability of methyl parathion hydrolase, OPHC2. Appl Microbiol Biotechnol 2010, 88, 125-31, https://doi.org/10.1007/s00253-010-2738-5.

25. Hawwa, R.; Larsen, S.D.; Ratia, K.; Mesecar, A.D. Structure-based and random mutagenesis approaches increase the organophosphate-degrading activity of a phosphotriesterase homologue from Deinococcus radiodurans. J Mol Biol 2009, 393, 36-57, https://doi.org/10.1016/j.jmb.2009.06.083.

26. Huang, Z.L.; Wu, B.P.; Wen, Q.; Yang, T.X.; Yang, Z. Deep eutectic solvents can be viable enzyme activators and stabilizers. Journal of Chemical Technology \& Biotechnology 2014, 89, 1975-1981, https://doi.org/10.1002/jctb.4285.

27. Lindberg, D.; de la Fuente Revenga, M.; Widersten, M. Deep eutectic solvents (DESs) are viable cosolvents for enzyme-catalyzed epoxide hydrolysis. $J$ Biotechnol 2010, 147, 169-71, https://doi.org/10.1016/j.jbiotec.2010.04.011.

28. Almirall, M.; Francesch, M.; Perez-Vendrell, A.M.; Brufau, J.; Esteve-Garcia, E. The differences in intestinal viscosity produced by barley and beta-glucanase alter digesta enzyme activities and ileal nutrient digestibilities more in broiler chicks than in cocks. $J$ Nutr 1995, 125, 947-55.

29. Neta, N.S.; Teixeira, J.A.; Rodrigues, L.R. Sugar ester surfactants: enzymatic synthesis and applications in food industry. Crit Rev Food Sci Nutr 2015, 55, 595-610, https://doi.org/10.1080/10408398.2012.667461. 
30. Gutierrez, M.C.; Ferrer, M.L.; Mateo, C.R.; del Monte, F. Freeze-drying of aqueous solutions of deep eutectic solvents: a suitable approach to deep eutectic suspensions of self-assembled structures. Langmuir 2009, 25, 5509-15, https://doi.org/10.1021/la900552b.

31. Vigier, K.D.O.; Chatel, G.; Jérôme, F. Contribution of Deep Eutectic Solvents for Biomass Processing: Opportunities, Challenges, and Limitations. ChemCatChem 2015, 7, 1250-1260, https://doi.org/10.1002/cctc.201500134.

32. Sampedro, J.G.; Uribe, S. Trehalose-enzyme interactions result in structure stabilization and activity inhibition. The role of viscosity. Molecular and Cellular Biochemistry 2004, 256, 319-327, https://doi.org/10.1023/B:MCBI.0000009878.21929.eb.

33. Wu, B.P.; Wen, Q.; Xu, H.; Yang, Z. Insights into the impact of deep eutectic solvents on horseradish peroxidase: Activity, stability and structure. Journal of Molecular Catalysis B: Enzymatic 2014, 101, 101107, https://doi.org/10.1016/j.molcatb.2014.01.001.

34. Suthiwangcharoen, N.; Nagarajan, R. Enhancing enzyme stability by construction of polymer-enzyme conjugate micelles for decontamination of organophosphate agents. Biomacromolecules 2014, 15, 1142-52, https://doi.org/10.1021/bm401531d. 